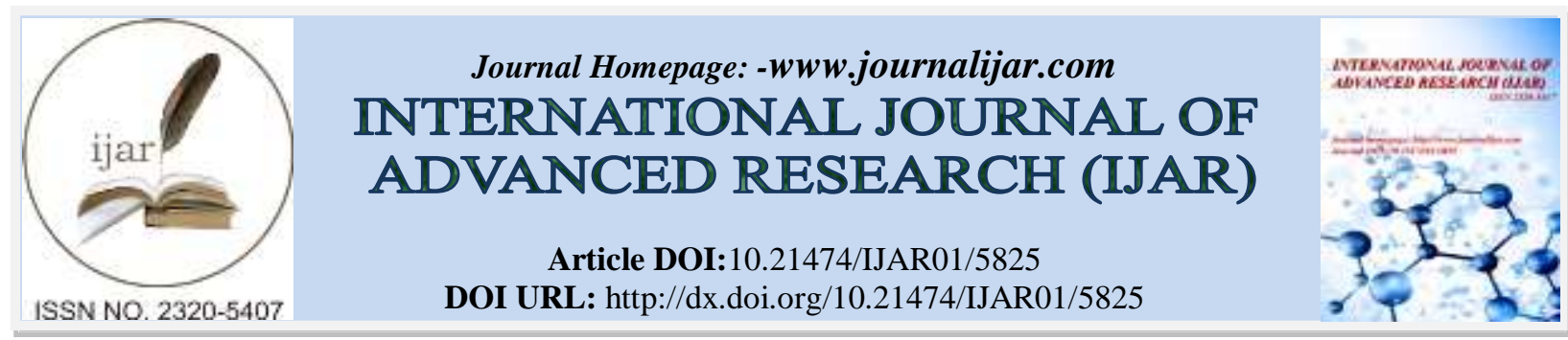

RESEARCH ARTICLE

\title{
BIBLICAL AND QUR'ANIC DISCOURSAL SHIFTS: GENERATING FREE MODES OF SPEECH AND THOUGHT PRESENTATION VIA 'ILTIFAT'.
}

Prof. Riyadh T. K. Al-Ameedi ${ }^{1}$ and Sadiq M.K. Al Shamiri ${ }^{2}$.

1. (Ph.D.)University of Babylon, College of Education for Human Sciences, Dept. Of English.

2. (Ph.D. Candidate)University of Babylon, College of Education for Human Sciences, Dept. Of English.

\section{Manuscript Info}

Abstract

Manuscript History

Received: 10 September 2017

Final Accepted: 12 October 2017

Published: November 2017

Copy Right, IJAR, 2017,. All rights reserved.

\section{Introduction:-}

English linguistic research has identified four free modes of speech and thought presentation: free direct speech (FDS), free indirect speech (FIS), free direct thought (FDT), and free indirect thought (FIT). The absence of the reporting clauses in the free constructions is the most important linguistic indicator which differentiates these free modes from their corresponding modes of presentation (direct speech, indirect speech, direct thought, and indirect thought) (see for instance, Leech and Short (1981, 2007); Quirk et al. (1985); Huddleston and Pullum (2002) ; Semino and Short (2004)).

However, the Arabic theory of الالتفات 'al-iltifat' 'discoursal shift' is assumed by the present study to explain the linguistic 'environment' which is required to form the free modes of speech and thought presentation; a free mode of speech or thought is generated by means of a discoursal shift from one type of discourse into another. This linguistic phenomenon is assumed to be universal as far as the Biblical and Qur'anic discourses are concerned.

Free Modes of Speech and Thought Presentation in English:-

In English linguistic research, the stylistic and syntactic accounts have identified four free modes of speech and thought presentation:

Free Direct Speech:-

According to Leech and Short (2007:258), free direct speech (FDS) is "a more direct form than DS". For Semino and Short (2004:11), writers make use of free direct speech by removing one or both of the most indicators of the reporter's presence in direct speech form: the reporting clause, and quotation marks.

Free direct speech differs syntactically from direct speech in one main point, which is the absence of "reporting clause', hence "the act of communication is signalled by, for example, shifts in the tense forms of verbs." The reporting clauses and quotation marks of free direct speech are often omitted, particularly in fiction writing "when the identity of the speakers is obvious from the context" (Quirk et al., 1985:1021-2). 
By free direct speech, the character interacts 'immediately' with readers without 'interference' of narrator. In narrative, this mode may "portray the quick to-and-fro" conversation between characters. Long conversations in novels may be constructed in this form because it is intended to express an "extra faithfulness" by providing the original words and grammatical structures. Its main effects are mainly those "vividness and dramatization" (Semino and Short, 2004:12). Sentences of free direct speech are employed "for purposes of textual economy as in ellipsis cohesion." Sequences of this mode can be used to produce "metronomic speech", where a speaker changes and labour of his identification is on the part of the reader (Toolan, 2009:1033).

\section{Free Indirect Speech:-}

According to Leech and Short (2007:261-4), free indirect speech (FIS) is a mixture of direct speech and indirect speech. In this mode, most typically, there is an omission of the reporting clause, but the main features of indirect speech, particularly backshift are returned.

Quirk et al. (1985:1032) point out that free indirect speech differs from direct speech in the following points: (a) the omission of the reporting clause, (b) the potentialities of direct speech sentence structure are retained (for example, direct questions and exclamations, vocatives, tag questions, and interjections, (c) it is similar to indirect speech in the "backshift of the verb, together with equivalent shifts in personal pronouns, demonstratives, and time and place references, that signals the fact that the words are being reported, rather than being in direct speech. Toolan (2009:1034) argues that preposed reported clauses, i.e., those in which the reported clause precedes the reporting one, are instances of free indirect speech. Such constructions have some features of direct speech (direct question, and exclamation, respectively), and 'indirect discourse' (ID) (backshift, tense, and distal or narratorial deictic).

In Huddleston and Pullum's (2002:1029) viewpoint, the absence of the reporting frame of indirect speech alone reduces it into 'free indirect discourse'. However, Toolan $(2009: 1034,1039)$ notes that the most prominent linguistic feature in FIS is 'modality', saying:

FIS is marked by frequent use of modal verbs (must, should, had to, could, might, would) and sentence adverbials (certainly, perhaps, maybe, surely, of course, etc.) expressing judgments about the likelihood or necessity or desirability of some action or state transpiring.

Leech and Short (2007:268) concentrate on the "ironic effect" of FIS, which is viewed to be the result of intervening of reporter between character and reader. Thus, "FIS is used as a vehicle for irony", because of its ability to express two points of view: the narrator's and the characters'. Declerck (2006:553) raises an important issue concerning this construction; free indirect speech is the acceptable report in the future.

\section{Free Direct Thought:-}

Leech and Short (2007:270) point out that the presentation of thought is concerned with "the portrayal of internal speech". That is to say, "the flow of thought through a character's mind", or what is known as "stream of consciousness." The modes of speech and thought presentation are similar in their formal features. By the same token, Quirk et al. (1985) consider all modes of reporting thoughts as types of reported speech. They (ibid:1021) observe the report to be "a representation of mental activity (internal communication), which by its nature is unspoken". They (ibid) consider free direct thought and free indirect thought as types of free direct speech and free indirect speech respectively. Similarly, Huddleston and Pullum (2002:1029) generalize the syntactic structure of free direct speech to free direct thought (see also Trauth and Kazzazi (2006:318)).

Greenbaum (1996:362) also considers free direct thought and free indirect thought as forms of free direct speech and free indirect speech respectively. He (ibid) states that in free direct speech, in addition to the omission of the reporting clause, present tense is used where appropriate, similar to direct speech (see also (Quirk et al., 1985:10323); (Declerck, 2006:812)) .

Leech and Short $(2007: 271,4)$ state that modes of thought presentation allow reader to "see things from that character's point of view." The employment of thought presentation modes involves the presence of an 'omniscient narrator'. As in speech presentation, direct thought and free direct thought give the impression that there is little intervention of the narrator. In extreme forms of free direct thought, associated with the absence of reporting clause and truncated sentences, a character may show reader how thoughts of a character may go by rapidly. Direct thought 
is often used in the form of "the dramatic mode of soliloquy", in an "attempt to make character's thought more actual." (ibid:275).

\section{Free Indirect Thought:-}

Leech and Short $(2007: 271,278)$ note that free indirect speech distances readers somewhat from the characters production of the speech. This is not the case with free indirect thought, which "has the opposite effect." It puts readers "directly inside the character's mind." Free indirect thought is a development of direct thought. It keeps the vividness of direct thought and avoids the "artificiality" of soliloquy, that is "speaking to oneself". Similar to speech presentations, writers can use thought presentation modes "strategically" in order to control their readers" "sympathies". This is done by giving extensive account of a character's (who is wanted to be sympathised with) thoughts in the form of free indirect thought. Characters who are not intended to be sympathised with are distanced by never shown their minds.

However, in free indirect thought no reporting verb is used, hence there is no overt signal that the character's rather than the author's view or thought is being portrayed (Downing and Locke, 2006:308).

\section{Free Modes of Speech and Thought Presentation in Arabic:-}

To the researchers' best knowledge, Arab scholars, grammarians and rhetoricians, whether early or contemporary, have identified only the direct and indirect forms of speech presentation under the concept of حكاية القول 'reported speech'. These are called حكاية معنى حكاية لفظ, respectively. However, they are aware of the existence of most of the modes of speech presentation. They discuss these modes under different grammatical and rhetorical labels. Discussions of omitted reporting clauses of حكاية القول 'reported speech' construction are not uncommon as they are considered as types of ellipsis.

According to الجرجاني d. 471 A.H. (1978:112), Arabic generally tends to adopt 'ellipsis' when it is appropriate to achieve eloquence because ellipsis is effective in producing concise speech and focusing meaning. Ellipsis ultimately aids the addressee concentrating on particular elements within the clause structure. Similarly, هثام d. 761 A.H. (2005: Vol.2: 410) maintains that the reported speech may be used with an omitted reporting clause: (1)

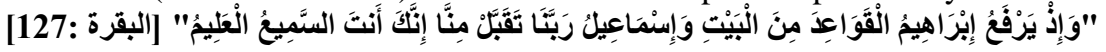

"Thus Abraham along with Ishmael laid the foundations for the House: 'our Lord, accept this from us! Indeed You are the Alert, the Aware!'” (Irving, 2011:20).

The omitted verb in this text is supposed to be '[يقول] و إسماعيل', 'and Ishmael [was saying]' (بن هشام d.761 A.H., 2005:Vol.2:410).

Contemporarily, الحموز (1984:587-95) suggests that the main purposes of using such type of ellipsis are rhetorical

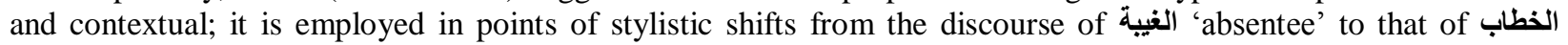

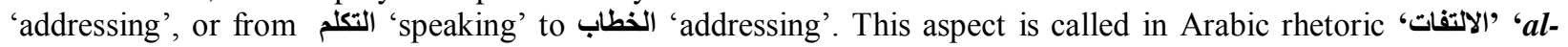
iltifat', and has already been referred to by الجواري' (1974:39), who considers such ellipsis as a type of التفات 'shift', which is that change of speech from narration to reporting, or the reverse. The shift may be from الأنثاء 'constative' to الخبر 'performative', or the reverse. He (ibid) puts it in the following way:

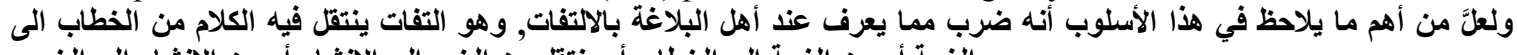

'Perhaps the most important noticeable thing concerning this style is that it is a sort of what is called by rhetoricians 'al-iltifat', which is a process by which the speech shifts from addressing discourse into the absentee or the reverse of this, or a shift from constative into performative or the reverse of this.'

However, most Arab scholars limit the discussion of the aspect of 'al-iltifat' to pronouns shifts; they seldom refer to shifts between constatives and performatives. Similarly, functions of the aspect of shift have not been systematically characterized either. Accordingly, to the researchers' best knowledge, this could be a modest attempt to characterize the free types of speech and thought presentation according to the Arabic rhetoric perspective of 'al-iltifat' 'discoursal shift'. 


\section{The Arabic Theory of Al-iltifat 'Discoursal Shift':-}

Lexically, the term التفات 'iltifat' is derived from the verbal form 'lafa', which may be used as a transitive

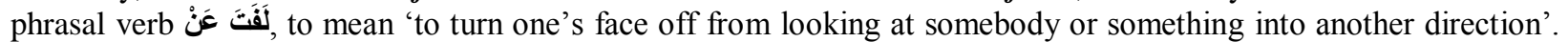
The term iltifat is used more generally to refer to that sudden abandonment of doing something (see ابن منظور d. 711 A.H. (2009, Vol. 2:95-7), and الرازي d. 666 A.H. (1983: 600-1)).

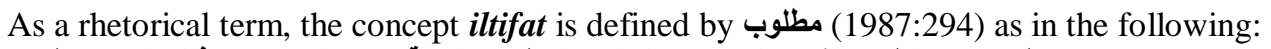

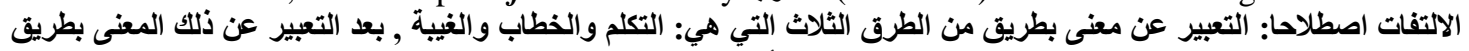
آخر من الطرق الثلاث بثرط أن يكون التعبير الثاني على خلاف ما يقتضيه الظاهر ويترقبه السامع.

'Al-iltifat in terminology is that expressing of meaning by three ways: speaker discourse, addressing discourse, and absentee discourse, after expressing that meaning by a different way from these three ones, providing that the second expression will be deviant from what is apparently required discourse, and from what is anticipated by hearer.'

According to درويش (2011:7), al-iltifat is one of the rhetorical aspects dealt with by early Arab rhetoricians. It mainly refers to that sudden alternative shift among pronouns, as in from using third person narrative into addressing discourse, or the reverse. The shift may be from addressing discourse into narrative discourse of speaking personal pronouns. Writers employ such shifts mainly in order to gain their readers' involvement and to avoid monotony which may result from keeping to one style.

However, the term الالتفات is no longer used to refer to that shift in the use of personal pronouns which ultimately affects the nature of discourse. According to the present study, the man who gave such issue its discoursalflavour is ابن حيان d.745 A.H. (1999, Vol.1:24) who identifies a new shift which can be considered as pragmatic. He calls it 'a shift from declarative into imperative'. This type is viewed by the present study as a shift from 'constative' into 'performative':(2)

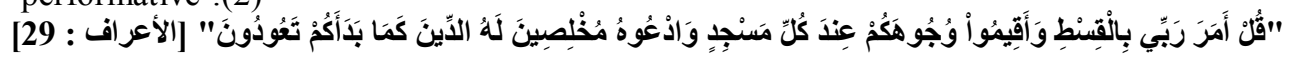

"SAY: 'My Lord has ordered me to play fair. Keep your faces set towards every place of prayer and appeal to Him sincerely; religion belongs to Him. Even as He started you off, so will you return"” (Irving, 2011:153).

ابن حيان d.745 A.H. (1999, Vol.1:24) argues that this text starts with a declarative (constative) in the past tense, and shifts into imperative (performative). He refers to two main additional types of shift:

"الرجوع من الغيبة الى (1) Shifting from absentee discourse into speaker one and the reverse.He (ibid) calls such shift

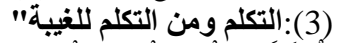

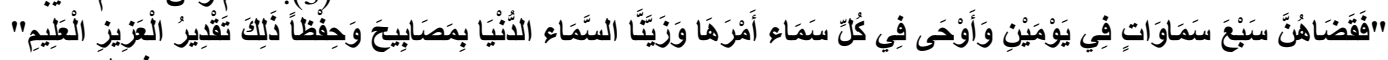

[12 : فصلت

"He determined there should be seven heavens [constructed] within two days, and inspired its own order in each heaven. We have beautified the lowest heaven with lamps and a safeguard. Such is the design of the Powerful, the Aware" (Irving, 2011:478).

(2) Telling past events by future forms, and the reverse:

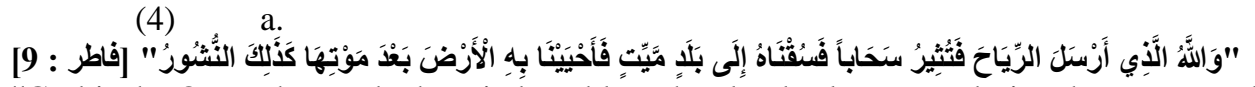

"God is the One Who sends the winds to blow the clouds along. We derive them on to a dead land, and revive the earth by means of them after it has died. Such is regeneration" (Irving, 2011:439).

b.

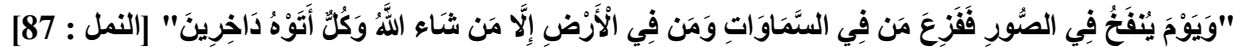

"Someday the Trumpet will be blown and startle whoever is in Heaven and whoever is on Earth, except for anyone God may wish. Everyone will come to Him abjectly" (Irving, 2011:384).

الأنثاء constatives' into الخبر 2002:144-5), as well, discusses two additional types of such discourse: from نصر الله 'performatives', and the reverse of this. Although she did not call them pragmatic, they are clearly so. As such, the present study prefers the term discoursal shift, which is hoped to appropriately label such language aspect. 


\section{Discourasal Shift Perspectives in Arabic Rhetoric:-}

In the history of Arabic rhetoric, two main fields have been concerned with discoursal shift: علم البعاني 'The Science of Meaning', and الزمخشري d. البديع d. 538 A.H. (2001:Vol.1:56), shifts form absentee into addressee, those from addressee to absentee, and the like, are natural phenomena in Arabic literature even before Islam, as in the following lines by Imru-alqayis:(5)

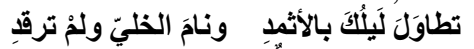

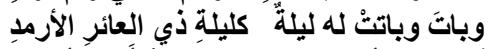

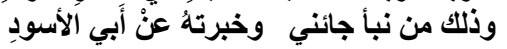

According to أبن حرويش in (2011:18), the first line opens with addressing discourse, the second shifts into absentee, and the third shifts into speaker discourse. The same shift and others are used in the Qur'an:

(6)

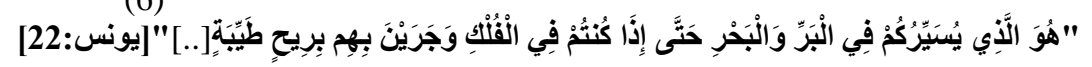

"He is the One Who sends you travelling along on land and at sea until when you are on board a ship, and sailing along under a fair wind [..]" (Irving, 2011:211).

Illustrating this, الزمخشري d. 538 A.H. (2001:Vol.1:56) thinks that such shifts attract the hearer's attention and stimulate him to listen more than a style that keeps to one discourse. This style may be intended to achieve some local (immediate) functions within the text.

Perspectives of discoursal shifts have been gradually established in Arabic Rhetoric; such shifts have been included within the domain of the Science of Meaning by Al-Sikaky d.626, with some references to it within the field of Beautiful Speech (مطلوب, 1987:Vol.1:298).

The aspect of discoursal shift is called by العدول عن مقتضى الظاهر" (1945:83) اليازجي", 'shift from what is apparently required [style]' whose main purpose is to hold the reader's attention.

states that most of Arab scholars consider الالتفات 'discoursal shift' as an aspect which belongs to the Science of Beautiful Speech, hence it is viewed as 'تزيين أسلوبي', 'stylistic (aesthetic) modification, or manipulation'. However, he (ibid) adopts the opinion of السكاكي, who considers this aspect to belong to the Science of Meaning. This aspect is employed to achieve some intended meanings; when the shift is into addressing discourse, it is often intended to present the addressee to praise or rebuke him, and the like. Shifting into absentee discourse is often intended to present the absent person to praise or glorify him. He (ibid) believes that this aspect reflects the inimitable nature of the Qur'anic discourse.

It is noticed that Arab rhetoricians have not limited the process of discoursal shift to that between adjacent sentences; a large stretch of texts of a Qur'anic Sura may adopt one discourse, then a sudden shift happens, as in the Opening Sura, which opens with four texts of absentee discourse, then shifts into addressing discourse. (see (بن حيان d.745 A.H. (1999, Vol.1:24); حسان (2000:Vol.2:98-102)).

It is also noticed that this aspect of discoursal shifts has been considered by Arabic Rhetoric apart from discussions of reported speech' perspectives. It seems that scholars have not been willing to discuss what they consider as grammar issues in rhetoric (similarly, grammarians have not referred to such shifts). Moreover, rhetoricians, whether early or contemporary have not referred to the possible effects of such discoursal shifts in generating what is called in modern terms free types of speech and thought presentation. Even when they identify some instances of such shifts that occasionally include reported speeches or thoughts, rhetoricians do not comment on the reported speech. Their efforts have mainly been concentrated on characterizing the shift to be belonging to a particular type, with occasionally some attempts to anticipate their functions.

\section{Types of Discoursal Shift:-}

Taking into account that types of discoursal shift are discussed by Arab scholars for other purposes apart from generating free types of reported discourse, each type is initiated by the available discussion offered by Arabic rhetoric, grammar, and interpretations of the Glorious Qur'an. This is done in order to identify the general intended functions of such shifts, and to discuss some misconceptions of those shifts and their meanings. Each section ends with an example of the way in which the shift generates a free type of reported speech. Instead of using the term 
'pronoun', the study considers the use of first person pronouns as a type of speaking discourse; the use of second person pronouns as addressing discourse; and the use of third person pronouns as a type of absentee discourse.

\section{Shift from Absentee into Addressing Discourse :-}

An instance of this type is already referred to above, which is in the Opening Surah of the Glorious Qur'an:

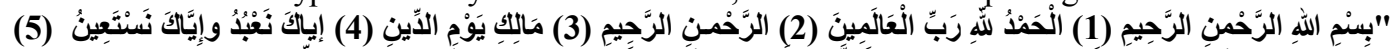

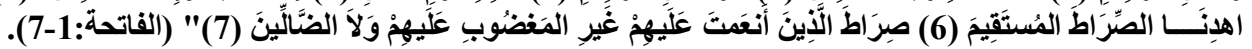

"[1] In the name of God, the Mercy-giving the Merciful [2] Praise be to God, Lord of the Universe, [3] the Mercygiving, the Merciful [4] Ruler on the Day of Repayment! [5] You do we worship and You do we call on for help.[6] Guide us along the Straight Road, [7] the road of those whom You have favoured, with whom You are not angry, nor who are lost!" (Irving, 2011:1).

According to الخوئي (2003:463), the Opening Surah of the Glorious Qur'an includes discoursal shift; it starts with an absentee discourse until the fifth text where the shift into addressing discourse occurs. The shift is intended to express, in الخوئي (ibid)'s words "حضور العبد بين يدي ربه ويخاطبه فالعبد حاضر بين يدي ربه غير غائب عنهة, "the attendance of the servant [man] in the presence of his Lord [Almighty Allah]. The servant talks to Him, as he is present, not absent. الخوئي (ibid) comments that Almighty Allah glorifies Himself in texts 1 to 4 using third person pronouns, then dictates His servants to recite text 5, that they will not worship or appeal to anyone, but only Him.

The study considers the following Qur'anic text as including a shift from absentee discourse into addressing one, and that shift generates free direct speech:(8)

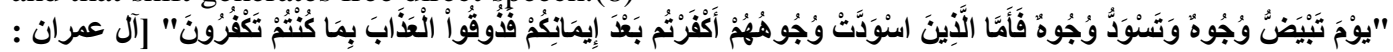

[106

"One day some faces will turn white while other faces will turn black. Those whose faces are blackened [will be asked]; 'Did you disbelieve after your [profession of] faith? Taste torment because you have disbelieved!'” (Irving, 2011:63).

This is also supported by (1973:54-5) who states that there are some occasions on which "تقدير القول assumption of the occurrence of saying' is also possible. Cases in which the reporting sentence is elided, where the implicit verb of saying is understood to complete the meaning, as in the above mentioned Qur'anic text. He (ibid) maintains that the omission of the reporting sentence is frequent in Arabic since such clauses can be understood from the surrounding context of كاية القول", 'reporting speech' which is in the above text "يوم تبيض وجوه وتسود وجوه",

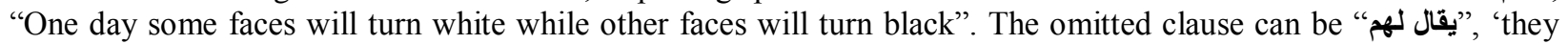
will be told/asked'.

\section{Shift from Absentee into Speaking Discourse :-}

الارويش (1988:Vol.2:142) thinks that the following text includes such a shift: (9)

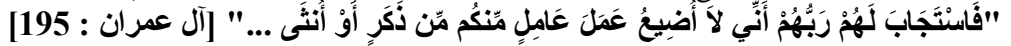

"So their Lord responded to them; 'I shall never waste the work of any worker among you, whatever it is a man or woman [..]" (Irving, 2011:76).

However, this Text is considered by the present study as a type of indirect speech (IS). The reporting clause is

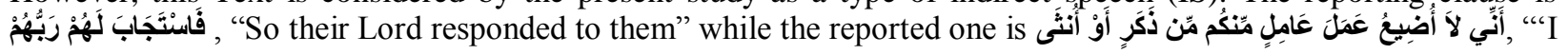
shall never waste the work of any worker among you, whatever it is a man or woman". The reported clause is reported indirectly since it is initiated with the particle أنَّ (عياد (النحاس d. 1988:114); 338 A.H. , 1977:Vol. $1 .: 494)$ ).

The following text represents the shift from absentee discourse into speaking discourse in which a free direct speech is generated:(10)

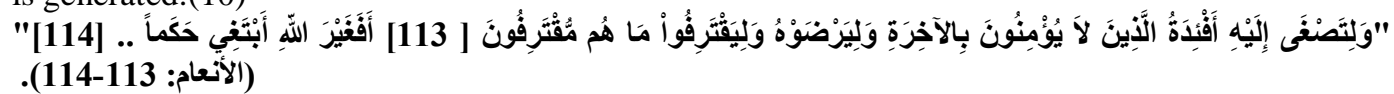


"Let the vital organs of those who do not believe in the Hereafter incline towards it, and let them feel satisfied with it and acquire whatever they may be acquiring. Should I crave someone besides God to settle matters? [...” (Irving, 2011:142).

Shift from Addressing into Absentee Discourse:-

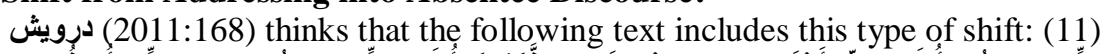

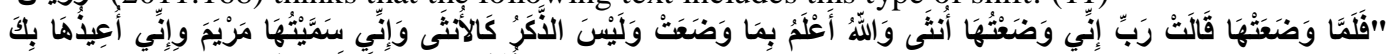

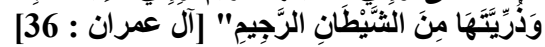

"When she gave birth, she said: 'My Lord, I have given birth to a daughter,' - (God was quite Aware of what she had given birth to, for a male is not like a female) -. 'I have named her Mary, and You to protect her and her offspring from Satan the Outcast'(Irving, 2011:54).

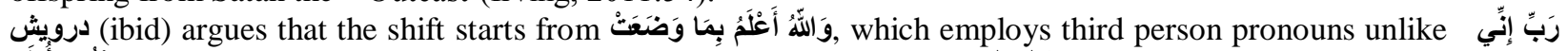

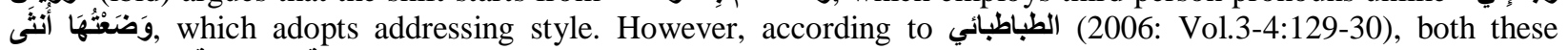
sentences are جملة اعتراضية parenthetical sentences' by Almighty Allah to mean that 'We know that she is a girl, but We want to achieve her mother's will in another better and acceptable way. Had her mother known Our will, she would not have regretted having her a girl'.

The idea of discoursal shift in the above text aids to identify the change of speaker. These comment clauses are inserted within a direct reported speech; the same quoted speech of the mother continues after them. As such, there should be a linguistic indicator to hold hearer's (reader's) awareness of that change of speaker. (The present study also considers such comment as 'external evaluation' since it is an apparent comment by The Narrator).

Another clear instance of a shift from addressing discourse into absentee one that produces free indirect speech is:(12)

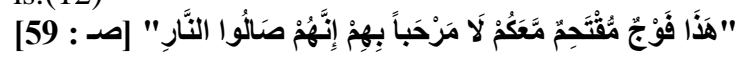

"Here comes a troop rushing at you! They have no welcome here, for they must roast in the Fire." (Irving, 2011:456).

The report generated by this type of discoursal shift is indirect reported speech since it is originally uttered by plural subjects (see (بن عاشور), 1984:Vol.5:87)).

Shift from Addressing into Speaking Discourse:-

According to السيوطي (2011:210), this type of shift is not found in the Glorious Qur'an. However, (2002:148) states that an instance of such a shift is found in the following verse:(13),

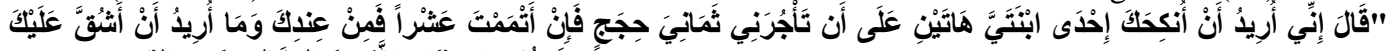

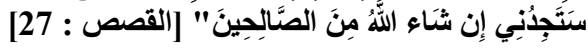

"He said: 'I want to marry you to one of these daughters of mine, provided you hire yourself out to me eight seasons. If you should complete ten, then that will be your own affair. I do not want to be hard on you; you will find me an honorable man, if God so wishes"” (Irving, 2011:388).

According to الطبرسي d. 502 A.H. (2005: Vol.7: 431), the underlined speech of the above text is by Prophet Shu'ayb (PBUH). This supports the argument that the shift is from addressing into speaking.

Shift from Speaking into Addressing Discourse:-

(2002:147) thinks that the following Qur'anic text represents this type of shift: (14)

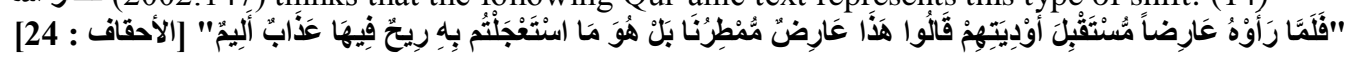

"When they saw it as a disturbance advancing on their valleys, they said: "This is some storm which will bring us rain.' Rather it was what you sought to hasten up for yourselves, a wind containing painful punishment," (Irving, 2011:505).

However, according to the present study, the shift is from absentee discourse into addressing one; the text starts with

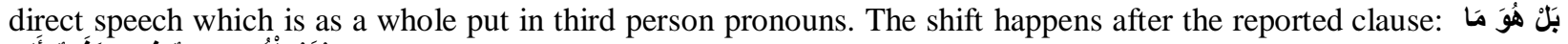

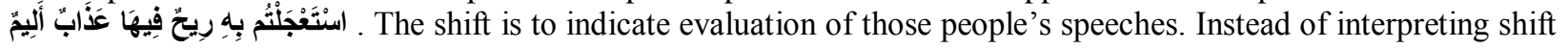


in terms of pronouns, considering the whole reported speech as a type of discourse provides a more objective interpretation of the shift.

\section{Shift from Constatives into Performatives:-}

According to جمال الدين (1980:258), one way of classifying Arabic sentences is that of خبرية 'constatives', and إنثائية 'performatives'. The former refers to that type of sentences which reveals or expresses already existed facts, as in 'It rained', السمائُ ماطرةٌ 'It will rain', and is raining'. These sentences describe facts that happened, are happening, or will happen. They can be described as true or false. The latter creates new states, i.e., such performative sentences do not reveal already existed states and cannot be described as true or false, because it is not possible to measure the new state according to an already existed one. Example of such performative sentences is أكتبْ الارسن 'Write the homework'. He (ibid:263) prefers this criterion of distinguishing constatives from performatives. However, Arab scholars enumerate instances of perfomatives and classify them into two main types:

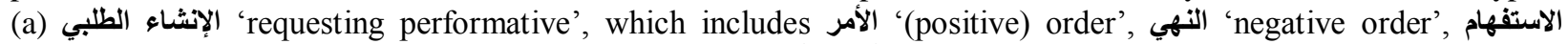

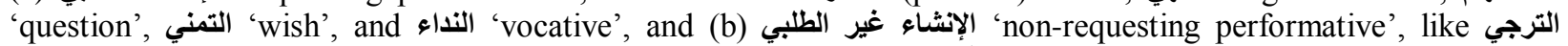

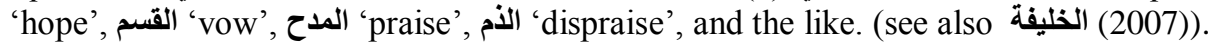

A shift from constative into performative may produce a free mode of speech or thought presentation, as in the following text in which the constative is underlined, while the performative is marked in bold type: (15)

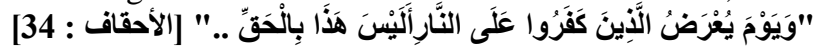

"Some day when those who disbelieve are exposed to the Fire [and asked]: 'Is this not real?'; [..]" (Irving, 2011:506).

The elided form in the above verse, according to (الطوسي) d.460 A.H. (2010:Vol.9:227) iss يقال لهم 'they will be told'.

\section{Shift from Performatives into Constatives:-}

Shifts of this type may generate free type of speech or thought presentation, too: (16)

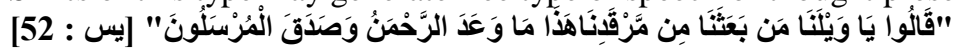

"They will say: 'It is too bad for us! Whoever has raised us up from our sleeping quarters? This is what the Mercy-giving has promised; the emissaries have been telling the truth" (Irving, 2011:443).

Shift from perfomative into constative produced that free direct speech of the disbelievers, which is at the same time a unique type of speech representation characteristic of Qur'anic discourse. It quotes speeches that will be uttered in the Day of Judgement (about the argument in the field of interpreting the Glorious Qur'an concerning the speakers of the above verse, see (الطوسي d.460 A.H. (2010:Vol.8:353-4)).

To sum up, the following table shows the discoursal shifts in Arabic that generate free modes of discourse.

Table (1):-Types of the Arabic الالتفات 'Discoursal Shift' that Generate Free Modes of Discourse

\begin{tabular}{|c|c|c|}
\hline Previous Discourse & Shift into & Free Modes \\
\hline Absentee & $\rightarrow$ & Addressing خطاب \\
\hline غيبةAbsentee & $\rightarrow$ & تكلمSpeaking \\
\hline Addressing & $\rightarrow$ & غيبةAbsentee \\
\hline Addressing & $\rightarrow$ & تكلم Speaking \\
\hline تكلمSpeaking & $\rightarrow$ & خطابAddressing \\
\hline خبر Constative & $\rightarrow$ & إنشاءPerformative \\
\hline Performative & $\rightarrow$ & Constative \\
\hline
\end{tabular}

The study assumes that discoursal shifts that generate free types of discourse are limited to the above mentioned seven types of shifts (Table 1). To test the validity of this hypothesis, some representative texts from the Qur'an and Matthew Version of the Gospel of the New Testament are going to be analysed. 


\section{The Model of Analysis:-}

The study adopts an eclectic discoursal model to analyse the targeted religious discourses. The model aims to identify the discoursal shifts associated with the free modes of speech and thought presentation within the Biblical and Qur'anic narrative contexts. It involves two main steps:

1. Identifying some representative extracts which include free modes of speech and thought presentation. The targeted free modes include 'free direct speech', 'free indirect speech', 'free direct thought', and 'free indirect thought'. These extracts are identified according to the English and Arabic accounts of the study in its theoretical part, particularly according to Leech and Short's (1981), and Semino and Short's (2004) stylistic models of speech and thought presentation.

2. The Arabic theory of 'al-itifat' is applied to the identified extracts to characterise the discoursal shifts associated with the free modes of speech or thought presentation. The study considers the use of first person pronouns as a type of speaking discourse; the use of second person pronouns as addressing discourse; and the use of third person pronouns as a type of absentee discourse. In addition shifts from constatives into performatives, and the reverse which associate the free modes are also considered. The pragmatic nature of the utterance in the latter types of shifts are decided according to the related findings of the English Speech Act Theory, and the Arabic perspectives of الخبر 'constative', and الإنثاء 'performative'.

The findings of the analysis of the 'representative extracts' is supported by a wider statistical account of the targeted uses of the free modes and the discoursal shifts in the Biblical and Qur'anic discourses.

\section{Data Analysis:-}

\section{Analysis of English Data:-}

The study has identified only free direct speeches in Matthew Version of the New Testament (The Gospel Part). The following is an analysis of four representative Biblical extracts in terms of the Arabic theory of al-iltifat.

\section{Extract (1):}

"3:10 And now also the axe is laid unto the root of the trees: therefore every tree which bringeth not forth good fruit is hewn down, and cast into the fire. 3:11 I indeed baptize you with water unto repentance. but he that cometh after me is mightier than I, whose shoes I am not worthy to bear: he shall baptize you with the Holy Ghost, and with fire: 3:12 Whose fan is in his hand, and he will throughly purge his floor, and gather his wheat into the garner; but he will burn up the chaff with unquenchable fire. 3:13 Then cometh Jesus from Galilee to Jordan unto John, to be baptized of him" (Matt.3[10-13]).

Texts 3:11-12 form a new 'quotative mode' of speech presentation, which is a free direct speech. It is a free direct speech of John since it offers a direct speech of him without a reporting clause, and without being subordinated or coordinated to the preceding reported clauses of the preceding direct speech. It employs first and second person pronouns. It is put in the form of some linked reported clauses. It seems that in presenting a long direct speech of John, the narrator unconsciously employs what is called in Arabic 'al-iltifat', which is that discoursal shift from one type of discourse into another. This technique is required in producing free types of speech and thought presentation. In this extract, the last coordinated 'reported clause' of the direct speech referred to in Text 3:10 can be seen as a kind of 'absentee discourse': "therefore every tree which bringeth not forth good fruit is hewn down, and cast into the fire". Although it is part of John's speech, he in that very clause sets a general statement using third person pronouns. Then in Text 3:11, John shifts into a "speaking discourse': "I indeed baptize you with water unto repentance. but he that cometh after me is mightier than I", producing a free direct speech.

\section{Extract (2):-}

"8:1 When he was come down from the mountain, great multitudes followed him. 8:2 And, behold, there came a leper and worshipped him, saying, Lord, if thou wilt, thou canst make me clean. 8:3 And Jesus put forth his hand, and touched him, saying, I will; be thou clean. And immediately his leprosy was cleansed.[...]" (Matt. 8[1-3]).

Text 8:3 also involves a use of free direct speech, 'be thou clean'. It is free since no reporting clause is used. The direct nature of the speech is obvious from the second person pronoun used and the form of the imperative. The technique of iltifat 'discoursal shift' is adopted to highlight the mode and attract the reader's attention and stimulate his involvement. The preceding direct speech identified in Text 8[3], 'I will' can be considered as a speaking discourse. It shifts into addressing discourse in the free direct speech, 'be thou clean'. The shift is also from constative into performative. 


\section{Extract (3):-}

"9:4 And Jesus knowing their thoughts said, Wherefore think ye evil in your hearts? 9:5 Forwhether is easier, to say, Thy sins be forgiven thee; or to say, Arise, and walk? 9:6 But that ye may know that the Son of man hath power on earth to forgive sins, (then saith he to the sick of the palsy,) Arise, take up thy bed, and go unto thine house. 9:7 And he arose, and departed to his house" (Matt. 9[2-7]).

Part of Text 9[6] also quotes a Jesus' speech. However, it is a direct speech without a reporting clause, hence its characterization as a free direct speech. The direct speech in Texts 9 [4-5] is at the same time an addressing discourse. Jesus is quoted to directly address some present addressees. Then, he shifts from one type of addressee (non-faithful people) into another type (the sick man). As a result, the process of discoursal shift is employed:

Extract (4):-

"26:64 Jesus saith unto him, Thou hast said: nevertheless I say unto you, Hereafter shall ye see the Son of man sitting on the right hand of power, and coming in the clouds of heaven. 26:65 Then the high priest rent his clothes, saying, He hath spoken blasphemy; what further need have we of witnesses?behold, now ye have heard his blasphemy. 26:66 What think ye? They answered and said, He is guilty of death" (Matt. 26[64-66]).

Text 26 [65] narrates the high priest's reaction to Jesus' answer, and quotes his speech. The high priest announces that there is no need to other witnesses since Jesus has spoken blasphemy. His speech is reported by means of two quotative modes of speech presentation: first, the mode of direct speech is employed: "the high priest rent his clothes, saying, He hath spoken blasphemy;". It includes a reporting clause, with its two obligatory elements: the subject 'the high priest', and the quotative verb (in its nominal form 'saying'); and a reporting clause, which is the rest of the speech. The reported clause itself is constative in nature. It is at the same time an absentee discourse; using third person pronouns. The high priest's direct speech continues, without being coordinated to the reported clause of the last one: "what further need have we of witnesses?". The new utterance is performative in nature; it is a rhetorical question. It is at the same time an 'addressing discourse'; using first person pronouns. The new quotative mode employed is free direct speech (1). The discourse shifts from constative to performative, and also from absentee discourse into addressing one. The priest's free direct speech continues further, also without a reporting clause: "behold, now ye have heard his blasphemy." The utterance is now a constative in nature, and also is an addressing discourse. This discoursal shift produces another free direct speech (2). Finally, the priest's speech shifts into perfomative: "What think ye?", which means another third free direct speech (3). The employment of discoursal shift spears the narrator's effort of repeating the reporting clauses of the direct speech. More importantly, it dramatises the speech and stimulates reader's involvement to live the event.

The study has identified only direct speeches within the targeted version of the New Testament. This mode has been employed for eight times only (in Texts 3:10, 6:3, 9:6, 11:27, 11:28, 26:66). All these uses are types of discoursal shift (Iltifat) of different forms.

Table (5) shows the types of discoursal shift of FDS in Matthew Version of the New Testament.

Table (5):-Types of Discoursal Shift 'Iltifat' in Free Direct Speech of Matthew Version of the New Testament

\begin{tabular}{|c|c|c|c|c|c|c|}
\hline No. & \multicolumn{4}{|c|}{ Type of Discoursal Shift 'Iltifat' } & Uses & Frequency \\
\hline 1 & ('speaking' $\rightarrow$ 'addressing') & 'تكلم' & $\rightarrow$ & 'خطاب' & 3 & $37.5 \%$ \\
\hline 2 & ('absentee' $\rightarrow$ 'speaking') & 'غيبة، & $\rightarrow$ & 'تكلم' & 1 & $12.5 \%$ \\
\hline 3 & ('addressing' $\rightarrow$ 'speaking') & 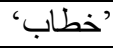 & $\rightarrow$ & 'تكلم' & 1 & $12.5 \%$ \\
\hline 4 & ('absentee' $\rightarrow$ 'addressing') & ' غيية'، & $\rightarrow$ & 'خطاب' & 1 & $12.5 \%$ \\
\hline 5 & ('performative $\rightarrow$ 'constative') & أنشاء & $\rightarrow$ & خبر & 1 & $12.5 \%$ \\
\hline 6 & ('constative' $\rightarrow$ 'performative') & خبر & $\rightarrow$ & أنشاء & 1 & $12.5 \%$ \\
\hline & Total & & & & 8 & $100 \%$ \\
\hline
\end{tabular}

\section{Analysis of Arabic Data:-}

\section{Discoursal Shifts of Free Direct Speech :-}

The majority of the examples in the previous theoretical account of discoursal shifts in Arabic are free direct speeches, with some instances of indirect speech. This is because in Arabic scholarly and linguistic research, discussion of حكاية القول 'reported speech' construction is limited to the direct and indirect reported speeches. However, two additional texts can be added. 


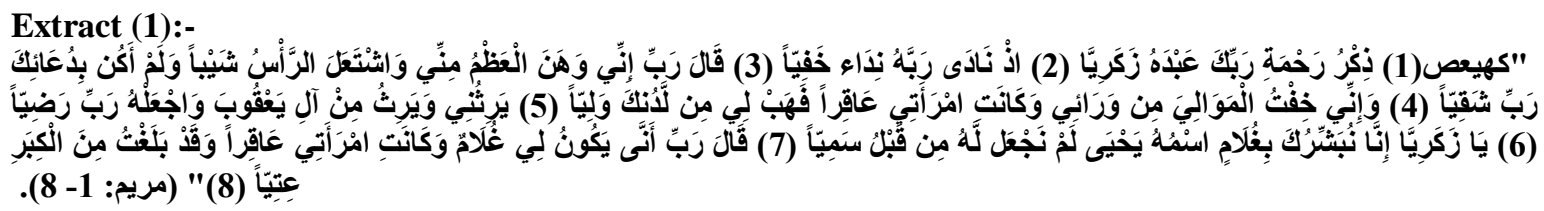

"[1] K.H.Y.E.S [2] (i) [This is ] a Reminder of your Lord's mercy towards his servant Zachariah [3] when he appealed to his Lord with a suppressed cry. [4] He said: "My Lord, my bones are tottering for me and my head is glistering with white hair, while I have never been grumbling in my appeal to you, my Lord! [5] Yet I fear for my heirs after me while my wife is barren, so grant me goodly an heir from Your presence. [6] who may inherit from me, and inherit from Jacob's house. Make him someone we can approve of, my Lord!" [7] Zachariah, We bring you news about a boy whose name will be John. We have not given such a name to anyone before." [8] He said: "My Lord, how will I have a boy while my wife is barren and I have reached such extreme old age?"(Irving, 2011:305-6).

Almighty Allah's acceptance of Zachariah's supplication is quoted in the form of free direct speech: “

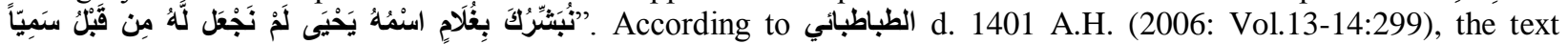

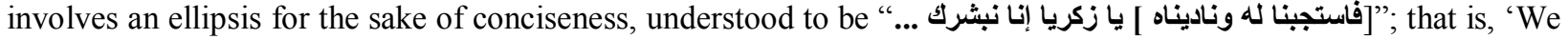
accepted his supplication, and called him 'Zachariah, We bring you news ..'. As such, the reporting clause is elided and the above form is the reported clauses of a free direct speech of Almighty Allah. The direct nature of the mode is indicated by the use of the first and second person pronouns of the speaker, 'Almighty Allah', which is put in the form of 'we' for glorification, and the addressee, 'you'. A discoursal shift 'Iltifat' is invested to generate this free direct speech. Zachariah's direct speech in Texts 4-6 is a kind of غيبه 'absentee discourse'. This is apparent from the use of the verb قال خطاب Text 7 shifts into خطال 'addressing' discourse.

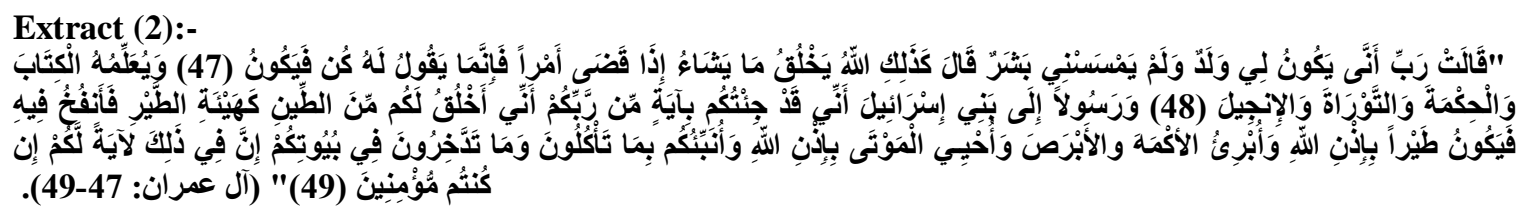

"[47] She said: "My Lord, how can I have a child while no human being has ever touched me?" He said: "That is how God creates anything He wishes. Whenever He decides upon some matter, He merely tells it: Be!, and it is. [48] He will teach him the Book and wisdom, plus the Torah and Gospel [49] as a messenger to the Children of Israel: I have brought you a sign from your Lord. I shall create something in the shape of a bird for you out of clay, and blow into it so it will become a [real] bird with God's permission. I shall cure those who are blind and lepers, and revive the dead with God's permission. I shall announce to you what you may eat and what you should store up in your houses. That will serve as a sign for you if you are believers, [50] conforming what I have already [learned] from the Torah. I shall permit you some things which have been forbidden you. I have brought you a sign from your Lord, so heed God and obey me!” (Irving , 2011:55-6).

The angel's speech, as an internal narrator, addressing Mary (PBUH) ends in Text 48, and Almighty Allah's speech,

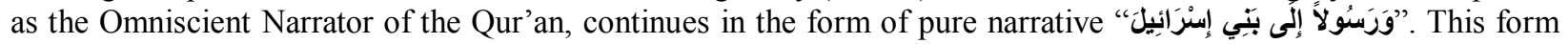
belongs to the absentee discourse. Then, there is a shift into تكلم 'speaking discourse'. This discoursal shift produces a free indirect speech in Text 49. From this to the end of the extract, Jesus (PBUH) talks about himself without using a reporting clause. This encourages the reader's (hearer's) involvement. The content of Jesus' speech is faithfully reported. However, the speech is not verbatim. This is expressed by the use of the particle which is called explanatory and used with the indirect types of reported speech in Arabic. The use of this particle recurs another time in “.."أني أخلق ". However, this cannot be taken as a start of another free indirect speech because the new clause

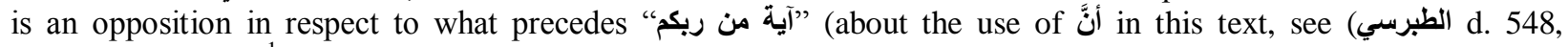
2005:Vol.2:296-7). ${ }^{1}$

${ }^{1}$ However, Text 49 embodies another 'reportive mode' of speech presentation which is a 'narrative report of speech

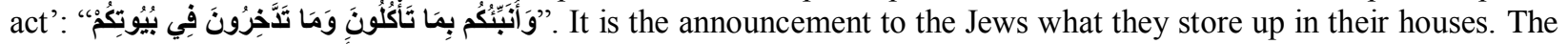

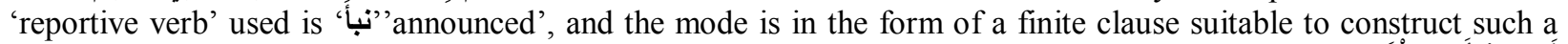

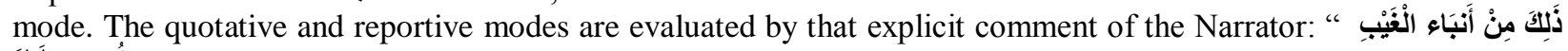
"نُوحِيهِ إَلَيكَ 
The total number of FDSs in the Qur'an is 45. All FDSs in the Qur'an are forms of 'Iltifat', i.e., 'discoursal shift':

1. 44.44\% of the Qur'anic FDSs are forms of discoursal shifts 'Iltifat' from 'خطاب' 'addressing discourse' into 'غيبة' 'absentee discourse'.

2. 26.66\% of the FDSs are forms of discoursal shifts from 'غيبة' 'خطاب' 'absentee discourse' into 'addressing discourse'.

3. 13.33\% of the Qur'anic FDs are formed by means of discoursal shifts from 'تخطاب' 'speaking' into' 'addressing'.

4. $\quad 6.66 \%$ of the Qur'anic FDSs are shifts from 'غيبة' 'absentee' into 'تكلم' 'speaking' discourses.

5. 4.44\% of the Qur'anic FDSs are forms of shifts from 'خطاب' 'تكلم' 'addressing' into 'speaking' discourses.

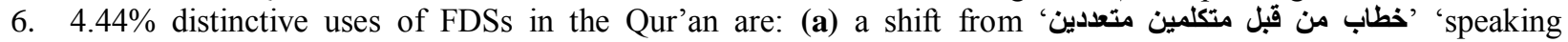

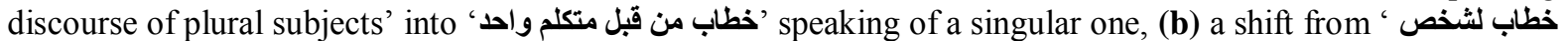

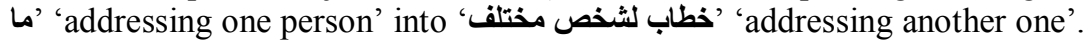

Table (2) shows FDSs in the Qur'an.

Table (2):-Discoursal Shifts of the Qur'anic Free Direct Speech

\begin{tabular}{|c|c|c|c|c|c|c|}
\hline No. & \multicolumn{4}{|c|}{ Type of Discoursal Shift 'Iltifat' } & Uses & Per. \\
\hline 1 & 'خطاب، & $\rightarrow$ & 'غيبة' & ('addressing' $\rightarrow$ 'absentee') & 20 & $44.44 \%$ \\
\hline 2 & 'غيبة' & $\rightarrow$ & 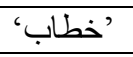 & ('absentee' $\rightarrow$ 'addressing') & 12 & $26.66 \%$ \\
\hline 3 & "تكلم' & $\rightarrow$ & 'خطاب، & ('speaking' $\rightarrow$ 'addressing') & 6 & $13.33 \%$ \\
\hline 4 & 'غيبة' & $\rightarrow$ & 'تكلم' & ('absentee' $\rightarrow$ 'speaking') & 3 & $6.66 \%$ \\
\hline 5 & 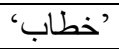 & $\rightarrow$ & 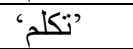 & ('addressing' $\rightarrow$ 'speaking') & 2 & $4.44 \%$ \\
\hline 6 & \multicolumn{3}{|c|}{ 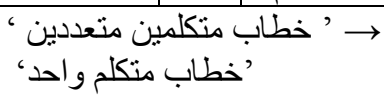 } & $\begin{array}{l}\text { ('speaking of plural subjects' } \\
\rightarrow \text { 'speaking of a singular one') }\end{array}$ & 1 & $2.22 \%$ \\
\hline 7 & \multicolumn{3}{|c|}{ 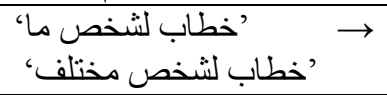 } & $\begin{array}{l}\text { ('addressing one person' } \\
\rightarrow \text { 'addressing another one') }\end{array}$ & 1 & $2.22 \%$ \\
\hline Total & \multicolumn{4}{|c|}{7} & 45 & $99.97 \%$ \\
\hline
\end{tabular}

Discoursal Shifts of Free Indirect Speech:-

Extract (3):

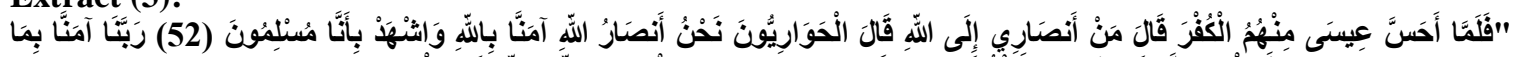

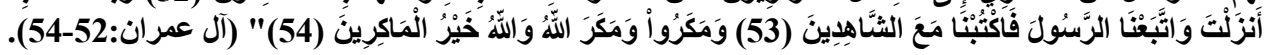

"[52] When Jesus sensed disbelief among them, he said: "Who will be my Supporters in the cause of God?" The disciples said: "We are God's supporters! We believe in God; take note we are Muslims. [53] Our Lord, we believe in what You have sent down and [thus] have followed the Messenger, so enrol use among the witnesses." [54] They plotted, while God plotted; however God is the best plotter!" (Irving, 2011: 56-8).

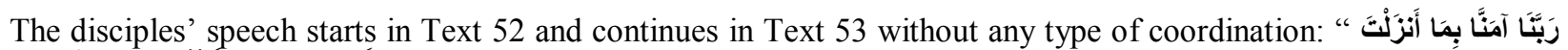

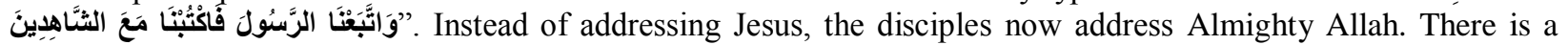
discoursal shift from 'addressing one particular addressee' into 'addressing another addressee'. This shift of discourse from الخطاب لمخاطب مختلف into الخطاب لمخاطب ما together with the absence of the reporting clause of the mode has provided the required discoursal environment of producing a free type of speech presentation, which is in this instance a free indirect speech. The above text is a matter of three reported clauses reported in the form of free

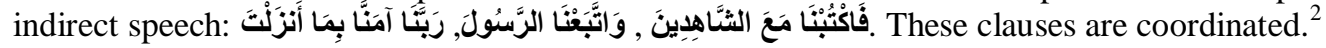

${ }^{2}$ The first clause of this free indirect speech involves an embedded 'narrative report of thought act'; the disciples report their own thought act of belief in Almighty Allah, which is beyond the limits of the present study.

Extract (4):-

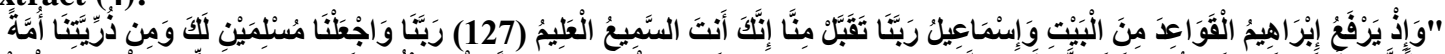

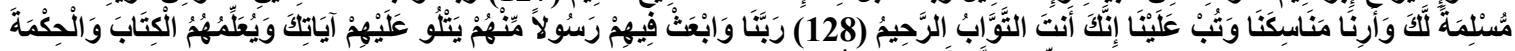

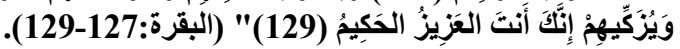


"[127] Thus Abraham along with Ishmael laid the foundations for the House: "Our Lord, accept this from us! Indeed You are the Alert, the Aware! [128] Our Lord, leave us peacefully committed to You, and make our offspring into a nation which is at peace with You. Show us our ceremonies and turn towards us. You are so Relenting, the Merciful! [129] Our Lord, send a messenger in among them from among themselves who will recite Your verses to them and teach them the Book and wisdom! He will purify them, for You are the Powerful, the Wise!"' (Irving, 2011:20-1).

Extract (4) is prefaced by Almighty Allah's narrative discourse speaking in the third person pronouns about Abraham and his son, Ismael (PBUT), as they are laying the foundations of the House. The discourse is غيبة 'absentee discourse'. While they are doing so, they appeal to Allah. Their speech is reported in the form of three connected utterances. Each part is initiated by the vocative 'رينا'. These parts are connected by means of repetition of this vocative form. All these three utterances belong to the same discourse which is addressing discourse by the same speakers, hence they belong to one mode of speech representation, which is free indirect speech. It is an indirect report of speech since it is uttered by dual subject (about the argument whether the speech is by Ishmael alone or by him and his father, see الطبرسي،d.548 A.H (2005:Vol.1:387)).

The Qur'anic free indirect speeches are produced by five forms of 'Iltifaat' 'discoursal shifts':

$70 \%$ of the free indirect speeches are forms of shifts from absentee into addressing discourses. $13.33 \%$ of the Qur'anic free indirect speeches are forms of shifts from constatives into performatives. One instant of FIS is by means of a shift from speaking into absentee discourses. There are $6.66 \%$ forms of FISs produced by shifts from speaking into addressing discourses. $6.66 \%$ other FISs are produced by shifts from addressing into absentee discourses.

Table (3) shows free indirect speeches in the Qur'an.

Table (3):-Discoursal Shifts of the Qur'anic Free Indirect Speech

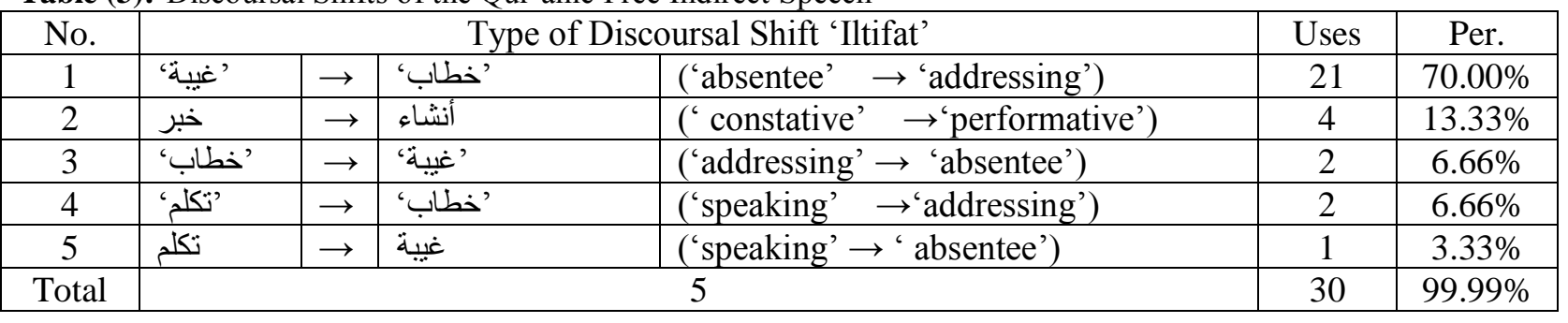

Discoursal Shifts of Free Direct Thought:-

Free direct thought (FDT) is characterized by the absence of the reporting clause, and that the thought is not addressed to any specific addressee:

Extract (5):-

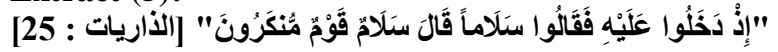

"when they entered his home and said: 'Peace [be upon you]!'? He said: 'On you be] peace!' [even though] they were people he did not know” (Irving, 2011:521).

The underlined text is an inner thought, because Ibrahim (PBUH) said it " such a way that visitors could not notice his feeling' (البروسي d.1137 A.H., 1989:Vol.4:148). This is also supported

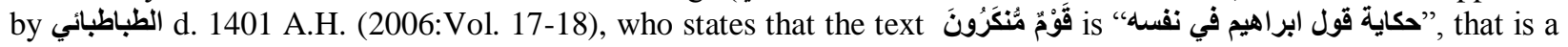
report of Ibrahim's (PBUH) inner speech. This mode is associated by a discoursal shift from addressing one particular addressee into addressing oneself. The form " "قوم منكرون "people whom I do not know' attracts reader's attention because it could not be used and audibly addressed within an answer of greeting.

Discoursal Shifts of Free Indirect Thought :-

Free indirect thought (FIT) is also characterized by the absence of reporting clause. It shares some features with indirect thought, and direct thought like backshift of pronouns, and direct questions, exclamations, repetitions: 
Extract (6):-

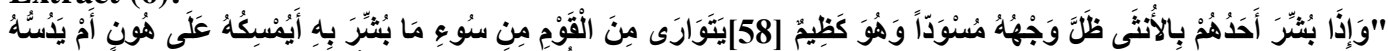

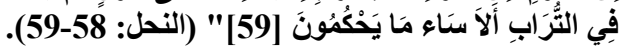

"Yet whenever one of them receives word he has had a daughter, his face becomes black with gloom and he feels like choking. He hides from folk because of the bad news that he has just received. Will he hold on to her and feel disgraced, or bury her in the dust? Whatever they decide is evil" Irving, 2011:273).

The underlined text above is an indirect report of thought. This is supported by interpretations of the Glorious Qur'an. The context represented by the preceding clause 'يَتَوَارَى مِنَ الْقَوْْ a proves that the underlined text is an inner thought. It is a free indirect thought because no reporting clause of thought is used, and because it employs third person pronouns.

In addition to the above text, free indirect thought is used two more times in the Glorious Qur'an:

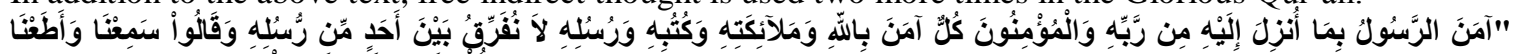

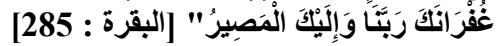

"The Messenger believes in what has been sent down to him from his Lord, and [so do] believers; everyone believes in God and His angels, His books and His messengers. We do not differentiate between any of His messengers. They say: 'we have heard and obey; [we beg] Your pardon, our Lord! Toward You lies the Goal!'” (Irving, 2011:49).

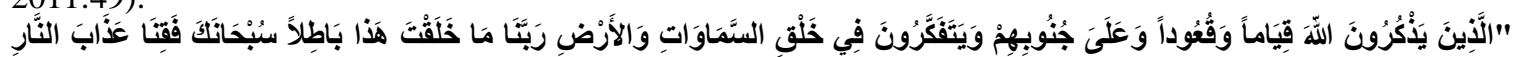

[191: آل عمران

"Who remember God while standing, sitting and [lying] on their sides, and mediate on the creation: of Heaven and Earth [by saying]: 'Our Lord, You have not created this in vain! Glory be to You! Shield us from the torment of Fire!"” (Irving, 2011:75).

The identified three uses of indirect thought in the Qur'an involve discoursal shifts. The first one is a form of shift from absentee discourse into speaking one. The second free indirect thought is a kind of shift from absentee discourse into addressing one, which is obviously at the same time a shift from constative into performative. The third free indirect thought is a form of shift from constative into performative.

Table (4) shows free indirect thoughts in the Qur'an.

Table (4):-Free Indirect Thoughts in the Qur'an

\begin{tabular}{|c|c|c|c|c|c|c|}
\hline No. & \multicolumn{4}{|c|}{ Type of Discoursal Shift 'Iltifat' } & Uses & Frequency \\
\hline 1 & 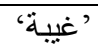 & $\rightarrow$ & "تكلم' & ('absentee' $\rightarrow$ 'speaking') & 1 & $33.33 \%$ \\
\hline 2 & غيبة & $\rightarrow$ & خطاب & ('absentee' $\rightarrow$ 'addressing') & 1 & $33.33 \%$ \\
\hline 3 & 'خبر، (خبر & $\rightarrow$ & 'إنثاء؛ & ('constative' $\rightarrow$ 'performative') & 1 & $33.33 \%$ \\
\hline Total & & & & 3 & 3 & $99.99 \%$ \\
\hline
\end{tabular}

\section{Conclusion:-}

It is concluded that the identified Biblical and Qur'anic free modes of speech and thought presentation are always associated by some types of discoursal shifts. The free modes of presentation in the Biblical discourse (Matthew Version of the Gospel) are limited to 'free direct speeches'. They are associated by six types of discoursal shifts: 'speaking' into 'addressing', 'absentee' into 'speaking', 'addressing' into 'speaking', 'absentee into addressing', 'performative' into 'constative', and 'constative' into 'performative'. The first type among these is the most frequently biblical discoursal shift. The Qur'anic discourse, on the other hand, employs all types of free modes of presentation: free direct speech, free indirect speech, free direct thought, and free indirect thought. All the theoretically identified seven types of discoursal shifts are employed in the Qur'anic discourse to generate these free modes of speech and thought presentation. Analysis of the Qur'anic free direct speech has revealed two additional types of discoursal shifts: 'speaking of plural subjects' into 'speaking of a singular one' and 'addressing one person' into 'addressing another person'. Analysis of the Qur'anic 'free indirect speech' uncovers an additional type of discoursal shift which is 'speaking' into 'absentee'. The Qur'anic free modes of thought presentation are rare, and the analysis of the free direct thought has added a new type of discoursal shift which is 'addressing a particular 
address' into 'addressing oneself'. The identified Biblical and Qur'anic discoursal shifts are employed in some climatic moments of narrative contexts. They are often intended to dramatise the narrated events and stimulate readers' interest and involvement.

\section{References:-}

English Sources :-

1. Bible, King James Version .(1997). Available at: http://www.quod.lib.umich.edu.

2. Downing, A., and P. Locke. (2006). English Grammar: A University Course. 2n ed. London: Routledge.

3. Declerck, R. (2006). The Grammar of the English Verb Phrase, Vol.1: The Grammar of the English Tense System: A Comprehensive Analysis. Berlin: Mouton de Gruyter.

4. Greenbaum, S. (1996). The Oxford English Grammar. Oxford: Oxford University Press.

5. Huddleston, R., and G. K. Pullum. (2002). The Cambridge Grammar of the English Language. Cambridge: Cambridge University Press.

6. Irving, T.B. (2011). The Qur'an. Tehran: Chap and Nashr International Publication.

7. Leech, G. and M. Short. (1981). Style in Fiction: A Linguistic Introduction to English Fictional Prose. $1^{\text {st }}$ Edition. London: Longman.

$8 . \quad$ (2007). Style in Fiction: A Linguistic Introduction to English Fictional Prose. $2^{\text {nd }}$ Edition. London: Longman.

9. Quirk, R., S. Greenbaum, G. Leech, and J. Svartvik. (1985). A Comprehensive Grammar of the English Language. London: Longman.

10. Semino, Elena and Mick Short. (2004). Corpus Stylistics: Speech, Writing and Thought Presentation in Corpus of English Writing. London: Routledge.

11. Toolan, M. (2009). "Speech and Thought: Representation of". In Mey, J. L. (ed.). Concise Encyclopedia of Pragmatics. $2^{\text {nd }}$ ed. Amsterdam: Elsevier Ltd, pp. 1029-1042.

12. Trauth, G. And R. Kazzazi. (Trans. And Edit.). (2006). Routledge Dictionary of Language and Linguistics. London: Routledge.

\section{Arabic Sources}

13. (1999)

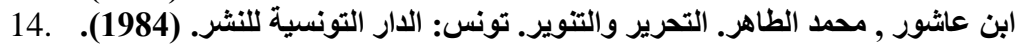

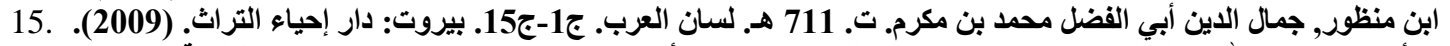

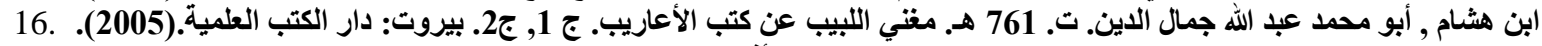

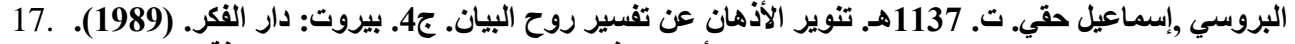

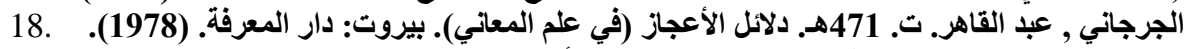

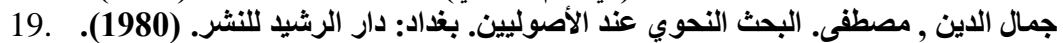

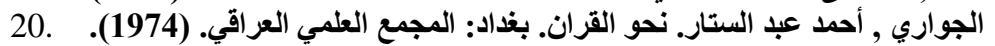

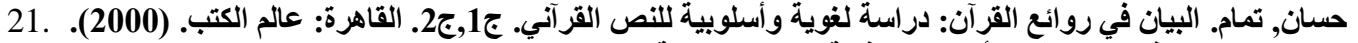

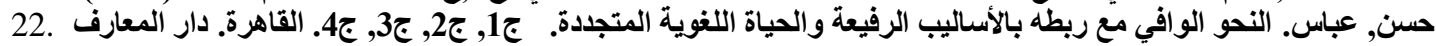
بمصر.(1973). (1984).

الحموز , عبد الفتاح أحمد. التأويل النحوي في القران الكريم. الرياض: مكتبة الرشيد. (1984).

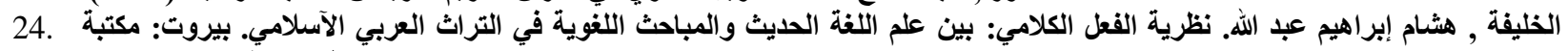

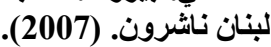

الخوئي , أبو القاسم بن علي أكبر بن هاشم الموسوي ت 1413هـ ـ البيان في تفسير القرآن. قم : مؤسسة إحياء تراث الامام الخوئي . . .(2003)

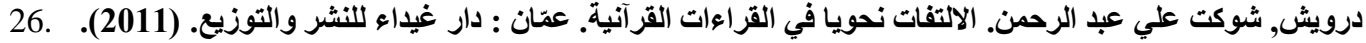

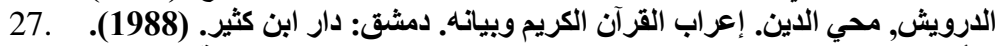

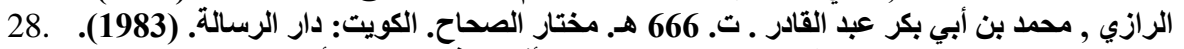

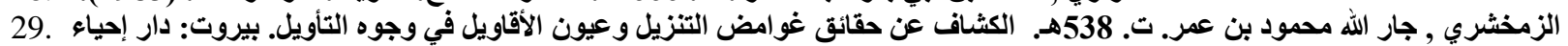

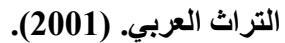

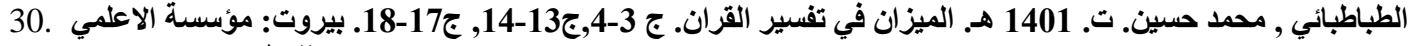
للمطبوعات. (2010).

الطبرسي, أبي علي الفضل بن الحسن السبزواري. ت. 548 هـ. مجمع البيان في تفسير القرآن. ج1, ج2, ج7. بيروت:مؤسسة .2015) الاعلمي للمطبو عات. (2005).

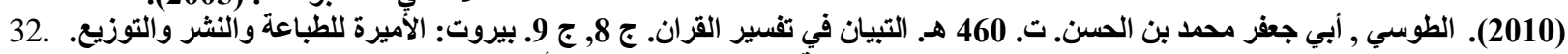

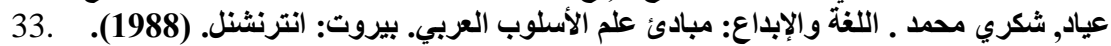


مطلوب, أحمد. معجم المصطحات البلاغية وتطورها ـ بغداد: المجمع العلمي العراقي. (1987).

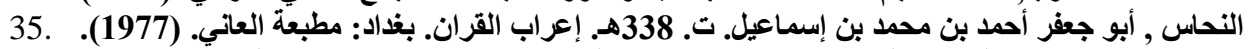

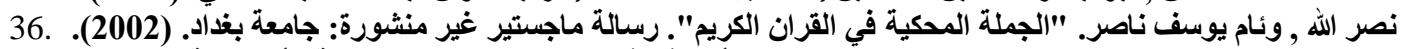

البازجي, ناصيف. ت. 1871 م. مجموع الأدب في فنون العرب. بيروت: المطبعة الأمريكانية. (1945). 